\section{CULTURAL ADAPTATION AND VALIDATION OF THE LOW ENERGY AVAILABILITY IN FEMALES QUESTIONNAIRE (LEAF-Q)}

ADAPTAÇÃO CULTURAL EVALIDAÇÃO DO LOW ENERGY AVAILABILITY IN FEMALES QUESTIONNAIRE (LEAF-Q)

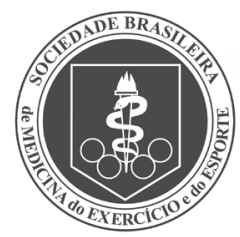

Original Article ARtigo ORIGINAL Artículo Original

\author{
ADAPTACIÓN CULTURAL YVALIDACIÓN DEL LOWENERGY AVAILABILITY IN FEMALES QUESTIONNAIRE (LEAF-Q)
}

\begin{abstract}
Uyara Pereira de Maria' (Nutritionist)

Claudia Ridel Juzwiak ${ }^{2}$ (DD

(Nutritionist)

1. Universidade Federal de São Paulo (UNIFESP), Interdisciplinary Postgraduation Program in Health Sciences, Santos, SP, Brazil. 2. Universidade Federal de São Paulo (UNIFESP), Department of Human Movement Sciences, Santos, SP, Brazil.
\end{abstract}

\section{Correspondence:}

Uyara Pereira de Maria.

Universidade Federal de São Paulo, Department of Human Movement Sciences, Campus Baixada Santista. Rua Silva Jardim, 136, Vila Matias, Santos, SP, Brazil. 11015-020. uyaramaria@uol.com.br

\begin{abstract}
Introduction: Low energy availability, amenorrhea and osteoporosis make up the Female Athlete Triad observed in physically active females and athletes. The Low Energy Availability in Females Questionnaire (LEAF-Q) was created with the purpose of identifying female athletes at risk for the Female Athlete Triad. Objective: To translate and culturally adapt the LEAF-Q for Brazilian Portuguese and validate it in a group of Brazilian athletes. Methods: The first stage of the study consisted of translation, cultural adaptation and content validation of the questionnaire in 20 athletes. In the second stage, for the test-retest reliability analysis and the construct validation, the final adapted version was applied in a sample of 127 athletes from various sports disciplines, 54 of whom responded to the questionnaire on a second occasion. For the test-retest reliability analysis, the intraclass correlation coefficient (ICC) was calculated and the paired t-test, McNemar's test and Bland-Altman plot were carried out. The construct validation modeled by known or contrasted groups was carried out by comparing the mean LEAF-Q scores of group 1 (athletes who practiced weight-sensitive sports) with those of group 2 (athletes who practiced team sports) using the Student's t test. Results: The Brazilian version of the LEAF-Q showed excellent test-retest reliability, with an ICC of 0.92 . The construct validity by known or contrasted groups was confirmed after demonstrating that athletes who practiced weight-sensitive sports had a higher LEAF-Q mean score than athletes who practiced team sports $(p \leq 0.05)$. Conclusion: The Brazilian version of the LEAF-Q is an important tool, which presented textual and cultural adequacy, proved to be reliable in terms of test-retest reliability, and presents evidence of validity to investigate the risk of the triad. Level of evidence II; Diagnostic Studies - Investigating a diagnostic instrument.
\end{abstract}

Keywords: Validation studies; Athletes; Female athlete triad syndrome.

\section{RESUMO}

Introdução: A baixa energia disponível, amenorreia e osteoporose compõe a tríade da mulher atleta, e afeta mulheres fisicamente ativas e atletas. O questionário Low Energy Availability in Females Questionnaire (LEAF-Q) foi criado com a finalidade de identificar atletas do sexo feminino em risco de tríade da mulher atleta. Objetivo: Traduzir e adaptar culturalmente para o português do Brasil e validar o LEAF-Q em um grupo de atletas brasileiras. Métodos: A primeira etapa do estudo consistiu em tradução, adaptação cultural e validação de conteúdo do instrumento em 20 atletas. Na segunda etapa, para a análise da confiabilidade teste-reteste e validação de construto, a versão final adaptada do questionário foi aplicada em uma amostra de 127 atletas de diversas modalidades e, dentre elas, 54 responderam o questionário em uma segunda ocasião. Para a análise da confiabilidade teste-reteste, foi calculado o coeficiente de correlação intraclasse (ICC), assim como a realização dos testes t pareado, de McNemar e do gráfico de Bland-Altman. A validação de construto modelada por grupos conhecidos ou contrastados foi realizada a partir da comparação das pontuações médias do LEAF-Q do grupo 1 (atletas de modalidades sensíveis ao peso) e do grupo 2 (atletas de esportes coletivos), empregando o teste t de Student. Resultados: A versão brasileira do LEAF- $Q$ apresentou excelente confiabilidade teste-reteste, com ICC de 0,92. A validade de construto por grupos conhecidos ou contrastados foi confirmada ao demonstrar que atletas de modalidades sensíveis ao peso têm pontuação média maior no LEAF-Q do que atletas de esportes coletivos ( $p \leq 0,05)$. Conclusão: A versão brasileira do LEAF-Q é uma ferramenta importante, que apresentou adequação textual e cultural, provou ser confiável, em termos de confiabilidade teste-reteste e apresenta evidências de validação para investigar o risco de tríade. Nível de evidência Il; Estudos diagnósticos - Investigação de um instrumento diagnóstico.

Descritores: Estudos de validação; Atletas; Síndrome da tríade da mulher atleta.

\section{RESUMEN}

Introducción: La baja energía disponible, amenorrea y osteoporosis conforman la Tríada de la mujer deportista, y afecta a mujeres físicamente activas y atletas. El cuestionario Low Energy Availability in Females Questionnaire (LEAF-Q) fue creado con la finalidad de identificar a atletas del sexo femenino en riesgo de Tríada de la mujer deportista. Objetivo: Traduciry adaptar culturalmente al portugués de Brasil y validar el LEAF-Q en un grupo de atletas brasileñas. Métodos: La primera etapa del estudio consistió en traducción, adaptación cultural y validación de contenido del instrumento 
en 20 atletas. En la segunda etapa, para el análisis de la confiabilidad test-retesty validación de constructo, la versión final adaptada del cuestionario fue aplicada a una muestra de 127 atletas de diversas modalidades y, entre ellas, 54 respondieron el cuestionario en una segunda ocasión. Para el análisis de la confiabilidad test-retest fue calculado el coeficiente de correlación intraclase (ICC), así como la realización de los tests t pareado, de McNemar y del gráfico de Bland-Altman. La validación de constructo modelada por grupos conocidos o contrastados fue realizada a partir de la comparación de las puntuaciones promedio del LEAF-Q del grupo 1 (atletas de modalidades sensibles al peso) y del grupo 2 (atletas de deportes colectivos), empleando el test t de Student. Resultados: La versión brasileña de LEAF-Q presentó excelente confiabilidad de test-retest, con ICC de 0,92. La validez de constructo por grupos conocidos o contrastados fue confirmada al demostrar que atletas de modalidades sensibles al peso tienen puntuación promedio mayor en el LEAF-Q que atletas de deportes colectivos $(p \leq 0,05)$. Conclusión: La versión brasileña del LEAF-Q es una herramienta importante, que presentó adecuación textual y cultural, probó ser confiable, en términos de confiabilidad de test-retest, y presenta evidencias de validación para investigar el riesgo de tríada. Nivel de evidencia ll; Estudios diagnósticos - Investigación de un instrumento diagnóstico.

Descriptores: Estudios de validación; Atletas; Sindrome de la tríada de la atleta femenina.

\section{INTRODUCTION}

Since 2007, the Female Athlete Triad has been described as a syndrome that consists of the interrelationship between low energy availability (LEA), with or without eating disorder, amenorrhea, and osteoporosis'. The syndrome, which has LEA as its main cause, can manifest itself in the most extreme condition or be found somewhere between the healthy and sick states. This can occur with any of its components ${ }^{1}$.

Energy availability (EA) is the energy available for metabolic processes after energy, relative to the fat-free mass, is used in physical exercise ${ }^{2}$. EA is calculated using the equation: [EA = energy intake $(E \mathrm{El})_{(\mathrm{kcal})}$ - exercise energy expenditure $(\mathrm{EEE})_{(\mathrm{kcal})} /$ fat-free mass $\left.(\mathrm{FFM})_{(\mathrm{kg})}\right]^{2}$. EA is considered adequate when $\geq 45 \mathrm{kcal} / \mathrm{kg}$ FFM/day and low when $\leq 30 \mathrm{kcal} / \mathrm{kg}$ FFM/ day, while subclinical symptoms can be identified when EA is between 30 and $45 \mathrm{kcal} / \mathrm{kg}$ FFM/day 3 .

Given that LEA plays a fundamental role in the development of the Triad, the diagnosis of this condition should focus on identifying the presence and cause of the LEA ${ }^{4}$. Although there is no standardized guide to determine this condition ${ }^{4}$, by definition, EA calculation requires information about El, EEE, and FFM ${ }^{5}$. However, measurement methods for these components are inaccurate or barely accessible ${ }^{5}$.

In view of the difficulty in measuring the components of $E^{6}{ }^{6}$, Melin et al. ${ }^{7}$ have developed and validated the Low Energy Availability in Females Questionnaire (LEAF-Q), a self-administered questionnaire, originally presented in English, consisting of 25 items related to menstrual and gastrointestinal status and the occurrence of injuries, which are factors associated with persistent energy deficiency that allow the identification of the risk for the Triad. The LEAF-Q has been validated in women, aged 18 to 39, who trained at least five hours a week, English, Swedish, and Danish dancers and endurance athletes, and it identifies athletes at risk for the Triad when the score is $\geq 8^{7}$. In addition, each domain of the questionnaire has a cutoff point that indicates dysfunction: $\geq 2$ for Injuries, $\geq 2$ for Gastrointestinal Function, and $\geq 4$ for Menstrual Function?.

The aim of this study was to translate, culturally adapt, and validate the Brazilian version of LEAF-Q as an instrument to identify athletes at risk for the Triad based on the analysis of reliability and construct validity by known-groups or contrasting groups method.

\section{METHODS}

\section{Translation, cultural adaptation, and content validation}

In order to translate the LEAF-Q into Brazilian Portuguese, the consent of the authors responsible for the original version of the questionnaire was obtained. The process to translate, culturally adapt, and validate the content of the LEAF-Q was carried out based on recommendations by Guillemin et al. ${ }^{8}$ and Beaton et al. ${ }^{9}$ (Figure 1).

The original version of the LEAF-Q was translated by two independent translators fluent in English. Translator 1, a specialist in the health field, knew the object of study. Translator 2 was an individual who was not an expert in the field and had no knowledge of the questionnaire. The two versions in Portuguese ( $\mathrm{T} 1$ and $\mathrm{T} 2$ ) were independently analyzed by three PhD professors of the health area (psychology, nutrition, and physical education) involved in sports. The three versions were synthesized by the main researcher into a single version in Portuguese (V1). V1 was back-translated into English by two native English translators and without knowledge of the content of the instrument, originating RT1 and RT2. Then, the original version, $T 1, T 2, V 1, R T 1$, and RT2 were independently analyzed by an expert committee composed of two health professionals (medicine and nutrition), working in the sport area and fluent in English, and one of the translators who participated in the previous translation process. Each member of the committee prepared a Brazilian version of the LEAF-Q, which were then synthesized by the researchers of this study into a single Portuguese version (pilot version).

For the content validation of the instrument, the pilot version was tested in order to identify potential problems of interpretation. Nine athletes from different sports disciplines, aged from 18 to 39 years, filled out the pilot version while they were observed regarding any doubt or difficulty related to the instrument. After filling it out, athletes were asked about the clarity of the questionnaire and if they had suggestions in cases of misunderstanding. The two following points were identified for adjustment: 1) one or more items were not answered because the expression "if yes" caused confusion among the athletes and, therefore, it was removed (Table 1); 2) when reading one of the questions in section $\mathrm{C}$, some athletes needed to review the original question in the section that was on the previous page; thus to improve the reading, a change was made as shown in Table 1.

After these adaptations, the new version, filled out by 11 other athletes, was defined as the final version of the Brazilian LEAF-Q, as there was no report of incomprehension or difficulties with the instrument.

\section{Participants}

One hundred and sixty female athletes, from different sports disciplines, were contacted. Participants should train for at least five hours/week aiming for competition, have had menarche, and be aged between 18 and 39 years. Pregnant athletes, lactating women, those with a chronic disease, users 


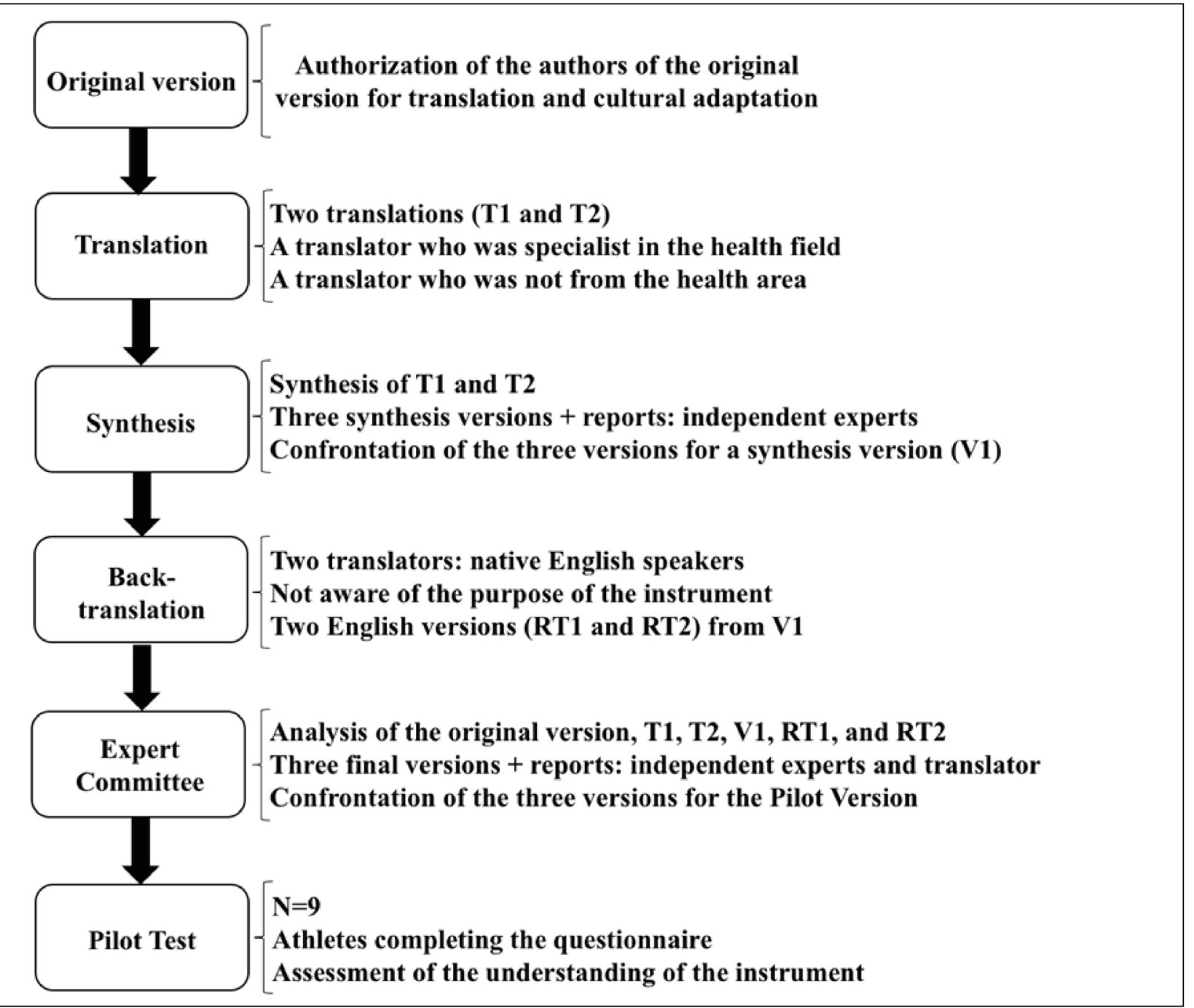

Figure 1. Flowchart of the stages of the process of translation, cultural adaptation, and content validation of the Low Energy Availability in Females Questionnaire (LEAF-Q).

Table 1. Changes to the pilot version, resulting in the final version (Brazilian version of the LEAF-Q).

\begin{tabular}{c|c}
\hline Pilot Version & Final Version \\
\hline $\begin{array}{c}\text { 3.2.C1. Se sim, quando foi sua } \\
\text { última menstruação? }\end{array}$ & Quando foi sua última menstruação? \\
\hline $\begin{array}{c}\text { 3.2.C2. Se sim, sua menstruação é } \\
\text { regular? (a cada } 28 \text { a } 34 \text { dias) }\end{array}$ & $\begin{array}{c}\text { Sua menstruação é regular? } \\
\text { (a cada } 28 \text { a } 34 \text { dias) }\end{array}$ \\
\hline $\begin{array}{c}\text { 3.2.C3. Se sim, por quantos dias } \\
\text { você tem sangramento? }\end{array}$ & Por quantos dias você tem sangramento? \\
\hline $\begin{array}{c}\text { 3.2.C4. Se sim, você já teve problemas } \\
\text { com sangramento menstrual intenso? }\end{array}$ & $\begin{array}{c}\text { Você já teve problemas com } \\
\text { sangramento menstrual intenso? }\end{array}$ \\
\hline $\begin{array}{c}\text { 3.2.C5. Se sim, quantas vezes vocêe } \\
\text { menstruou nos últimos 12 meses? }\end{array}$ & $\begin{array}{c}\text { Quantas vezes você menstruou } \\
\text { nos últimos } 12 \text { meses? }\end{array}$ \\
\hline $\begin{array}{c}\text { 3.2.C6. Se você respondeu "não" ou "eu } \\
\text { não me lembro" na questão C, quando } \\
\text { você teve sua última menstruação? }\end{array}$ & $\begin{array}{c}\text { Se você respondeu "não" ou "não sei" na } \\
\text { questão C (Sua menstruação é normal?), } \\
\text { quando você teve sua última menstruação? }\end{array}$ \\
\hline
\end{tabular}

of hormonal contraceptives (or who used oral contraceptives six weeks before the study), those who had any injury that prevented them from training for two weeks or more, and those participating in the first stage of the study (content validation) were not included. Thirty-three athletes reported use of hormonal methods of contraception and therefore were not part of this study. The sample consisted of 127 athletes from the following sports: running, triathlon, swimming, cycling, rhythmic gymnastics, jiu-jitsu, Muay Thai, mixed martial arts (MMA), rugby, football, basketball, volleyball, handball, and CrossFit*.
The participants signed an informed consent form. The Research Ethics Committee of the Federal University of São Paulo has approved this study with reference number 2.044.177/2017.

\section{Reliability}

Reliability is the ability of the questionnaire to produce the same results in repeated tests under various conditions ${ }^{10}$. For the analysis of the test-retest reliability of the Brazilian version of the LEAF-Q, of the 127 participants, 54 completed the instrument in two moments, in an interval of two to four weeks, without knowing the first result and in the same menstrual cycle. Because of the self-administered characteristic of the questionnaire, there was no influence of the researcher on the responses of the participants at any time.

\section{Construct validity}

Construct validity can be accessed by the degree of correlation between the scores of an instrument and the hypotheses about the concept being measured ${ }^{11}$. To verify the construct validity of the Brazilian version of the LEAF-Q, the approach of known-groups or contrasting groups was adopted. The assumed hypothesis was that weight-sensitive sports (disciplines of endurance, aesthetics, and combat) athletes (group 1) would have a higher mean LEAF-Q score than team sports athletes (group 2). Weight-sensitive sports are defined as those in which restrictive diets, low adiposity, frequent fluctuations in body mass, and eating disorders are reported in the literature and in practice $^{12}$. 


\section{Statistical analysis}

Demographic and anthropometric characterization data were submitted to descriptive analysis and results presented as mean and standard deviation (SD) values.

Test-retest reliability was assessed using the Intraclass Correlation Coefficient (ICC). The recommended ICC value should be the closest to +1 , with a minimum acceptable value of $0.70^{13}$. In the Bland-Altman ${ }^{14}$ plot, the individual differences between the test-retest scores were plotted against the mean of both scores. The 95\% agreement limits were calculated as the mean difference between the test and retest scores \pm 1.96 SD of the differences.

McNemar's test ${ }^{15}$ was used to compare the diagnosis of risk for the Triad in the test-retest, with the null hypothesis $p>0.05$ as desirable, which demonstrates the absence of a change in the diagnosis in this interval. The paired t-test between the means of the test and retest scores was performed with the expectation of no statistical difference between them.

For the analysis of construct validity by known-groups or contrasting groups, Student's t-test was used to compare the mean LEAF-Q score of weight-sensitive sports athletes with that of team sports athletes.

The data were processed using the program Statistical Package for the Social Sciences - SPSS, version 22.0, for Windows 7.0 ${ }^{16}$. To interpret the results and the hypothesis tests, significance values equal to or less than $5 \%(p \leq 0.05)$ were adopted.

\section{RESULTS}

\section{Reliability}

Table 2 shows the demographic and anthropometric characteristics of the participants.

The Brazilian version of the LEAF-Q showed excellent reliability with an ICC of 0.92 .

The measurement of the test-retest scores of the 54 athletes showed a normal distribution, which allowed the analysis of the Bland-Altman plot. Figure 2 shows that 95\% of the differences between the 1 st and 2 nd measurements were between -4 and +4 points $(p=0.58)$. Similarly, the result of the paired t-test between the mean test-retest scores was $p=0.61$.

McNemar's test was applied to assess the intra-subject change in the risk for the Triad. It was observed that there was no significant change $(p=0.50)$ between test and retest in this sample, thus reinforcing the reliability of the Brazilian version of the questionnaire.

\section{Construct validity}

The construct validity by known-groups or contrasting groups of the Brazilian version of the LEAF-Q was verified when observing a higher mean score of the questionnaire in group 1, when compared with the mean score of group 2, in the two moments of application of the instrument (Table 3).

Table 4 shows the anthropometric characteristics of the participants of each group.

Table 2. Characteristics of the sample.

\begin{tabular}{c|c}
\hline \multirow{2}{*}{ Variables } & $\mathbf{n = 1 2 7}$ \\
\cline { 2 - 2 } & Mean (SD) \\
\hline Age (years) & $27(6.4)$ \\
\hline Height $(\mathrm{cm})$ & $165.8(7.4)$ \\
\hline Body mass $(\mathrm{kg})$ & $64.3(9.1)$ \\
\hline BMl $\left(\mathrm{Kg} / \mathrm{m}^{2}\right)$ & $23.4(2.8)$ \\
\hline Training hours $/$ week (h) & $11.3(5.8)$ \\
\hline LEAF-Q score & $6.2(3.6)$ \\
\hline
\end{tabular}

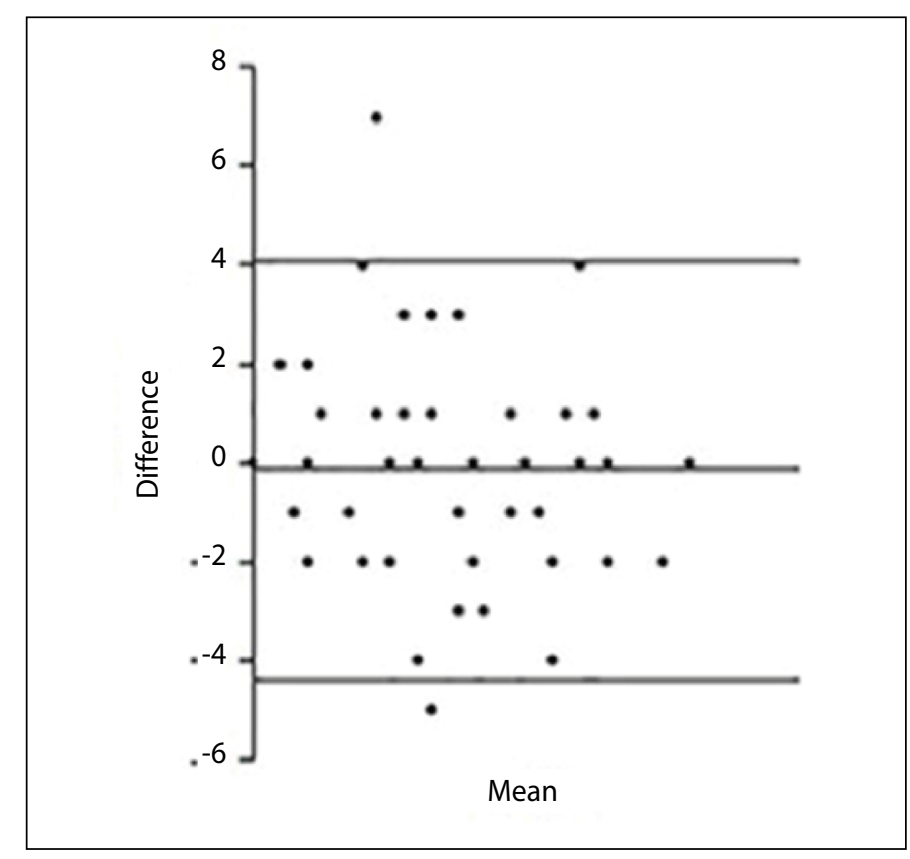

Figure 2. Bland-Altman plot regarding agreement between test and retest, applied in an interval of two to four weeks.

Table 3. Mean LEAF-Q score for groups 1 and 2 on the test and retest.

\begin{tabular}{c|c|c|c|c}
\hline & \multicolumn{2}{|c|}{ Test } & \multicolumn{2}{c}{ Retest } \\
\hline & $\mathbf{n}$ & LEAF-Q & $\mathbf{n}$ & LEAF-Q \\
\hline Group 1 & 38 & $7.8(3.7)^{*}$ & 20 & $8.8(4.3)^{*}$ \\
\hline Group 2 & 57 & $5.2(3.2)$ & 27 & $5.1(3.4)$ \\
\hline
\end{tabular}

${ }^{*} p \leq 0.05$ between groups 1 and 2 . Mean (SD).

Table 4. Sample characteristics of athletes from groups 1 and 2.

\begin{tabular}{c|c|c}
\hline & Group 1 & Group 2 \\
\hline & $\boldsymbol{n = 3 8}$ & $\boldsymbol{n = 5 7}$ \\
\hline Age (years) & $30(6.5)^{*}$ & $23.5(4.6)$ \\
\hline Height (cm) & $165(6.8)$ & $167(7.6)$ \\
\hline Body mass (kg) & $63(9.4)$ & $64.4(9.1)$ \\
\hline BMl $\left(\mathrm{Kg} / \mathrm{m}^{2}\right)$ & $23.1(2.8)$ & $23.1(3.1)$ \\
\hline Training hour/week (h) & $12.9(6.5)$ & $10.7(5.9)$ \\
\hline
\end{tabular}
${ }^{*} p \leq 0.05$. Mean (SD).

\section{DISCUSSION}

The method used in this study allowed the translation, cultural adaptation, and validation of the LEAF-Q to be carried out for application in Brazilian athletes in order to identify the risk for the Triad from symptoms related to LEA. The instrument, in its Brazilian version, does not present linguistic or cultural bias, and, therefore, allows the identification of athletes at risk for the Triad.

Despite the lack of consensus, some aspects are identified as important in the process of translating and adapting an instrument: 1) the translation needs to be performed by more than one person with a high level of knowledge of the original language and the target language, and who is familiar with both cultures ${ }^{17}$;2) the role of the expert committee is essential in reviewing all translation versions, in making decisions to reach consensus on discrepancies found, and in consolidating the process to produce the final version ${ }^{18}$; and 3) the elaborated version of the instrument must be tested on the target audience to guarantee the scope, objectivity, simplicity, clarity, relevance, credibility, variety, and semantic and idiomatic range of the content based on the impressions of this population ${ }^{19}$. All of these aspects were adopted in this study.

During the translation and adaptation of the LEAF-Q, there was no change in the format of the original questionnaire or its items. The linguistic and cultural changes proposed by the expert committee were 
made to provide greater understanding by the Brazilian population. There is an adapted version of the LEAF-Q for New Zealand physical activity practitioners ${ }^{20}$. In this version, some words and expressions were replaced for a better understanding by the New Zealand population, as the original version of the LEAF-Q was developed in Scandinavia ${ }^{21}$. However, there were no reports of content validation in the target population. Similarly, Meng et al. ${ }^{22}$ have applied the LEAF-Q to Chinese athletes, but they have not mentioned translating and adapting the instrument to this population. Thus, so far, this is the only study that has translated and culturally adapted the LEAF-Q according to recommendations $s^{8,9}$.

The test-retest reliability of the Brazilian version of the LEAF-Q, in an interval of two to four weeks, had an excellent ICC of 0.92. The interval to repeat the measurement should be long enough to prevent the volunteer from remembering the answers, but short enough to ensure that clinical change has not occurred ${ }^{23}$. Therefore, in this study, only athletes who did not have a new menstrual cycle between test and retest completed the instrument for the second time, thus ensuring that they would not have experienced and observed different characteristics from the previous cycle, when they filled out the questionnaire for the first time. The original version, developed and validated by Melin et al. ${ }^{7}$, had an adequate ICC of 0.79 and a test-retest interval of two weeks, with no indication whether the athletes were in the same menstrual cycle.

Construct validity aims to support the ability of the instrument to measure what it is designed to measure ${ }^{24}$ and can be assessed from predefined hypotheses, such as, for example, expected differences in scores between "known" groups ${ }^{13}$. The hypothesis of this study was based on the claim by Ackland et al. ${ }^{25}$ that weight-sensitive sports athletes (gravitational, aesthetic, and weight sports) use extreme methods of caloric restriction to quickly reduce or maintain body mass in order to obtain competitive advantage, being thus more susceptible to LEA and, consequently, to Triad. The claim has corroborated the study by Torstveit and Sundgot-Borgen ${ }^{26}$, who have observed a lower risk for the Triad in team sports athletes when compared with endurance, combat, and aesthetic sports athletes. Thus, the validity by known-groups, of the Brazilian version of the LEAF-Q, was satisfactory as it proved that weight-sensitive sports athletes had a higher risk for the Triad in relation to team sports athletes. Despite the correlation shown in this study, Logue et al. ${ }^{27}$ have been unable to find a difference in the LEAF-Q score between Irish athletes and practitioners of individual and team sports.

The original LEAF-Q showed a sensitivity of $78 \%$ and specificity of $90 \%$ obtained by analyzing the criterion validity ${ }^{7}$, which was not performed in the present study, but which is suggested for future psychometric evaluations of the instrument. The lack of other validated questionnaires to identify the risk for the Triad, or its components, prevented us from comparing the diagnostic efficacy of the LEAF-Q and, consequently, the scope of the construct validity analysis.

\section{CONCLUSION}

The Brazilian version of the LEAF-Q showed contextual and cultural adequacy, proved to be reliable in terms of test-retest reliability, and has validation evidence to identify the risk for the Triad in Brazilian athletes. This is the first study that has translated LEAF-Q into Brazilian Portuguese, evaluating its reliability and construct validity.

\section{ACKNOWLEDGMENTS}

This work had the support of the Coordenação de Aperfeiçoamento de Pessoal de Nível Superior (CAPES).

All authors declare no potential conflict of interest related to this article

AUTHORS'CONTRIBUTIONS: Each author made significant individual contributions to this manuscript. UPM: development of the research project, writing, data collection, statistical analysis, analysis and interpretation of the data, and revision; CRJ: intellectual concept, study design, development of the research project, writing and analysis and interpretation of the data, revision and approval of the article.

\section{REFERENCES}

1. De Souza MJ, Nattiv A, Joy E, Misra M, Williams NI, Mallinson RJ, et al. 2014 Female Athlete Triad Coalition consensus statement on treatment and return to play of the female athlete triad: 1st International Conference held in San Francisco, CA, May 2012, and 2nd International Conference held in Indianapolis, IN, May 2013. Clin J Sport Med. 2014;24(2):96-119.

2. Nattiv A, Loucks AB, Manore MM, Sanborn CF, Sundgot-Borgen J, Warren MP, et al. American College of Sports Medicine Position Stand. The female athlete triad. Med Sci Sports Exerc. 2007;39(10):1867-82.

3. Schofield KL, Thorpe H, Sims ST. Resting metabolic rate prediction equations and the validity to assess energy deficiency in the athlete population. Exp Physiol. 2019;104(4):469-75.

4. Mountjoy M, Sundgot-Borgen J, Burke L, Carter S, Constantini N, Lebrun C, et al. The IOC consensus statement: beyond the Female Athlete Triad - Relative Energy Deficiency in Sport (RED-S). Br J Sports Med. 2014;48(7):491-7.

5. Burke LM, Lundy B, Fahrenholtz IL, Melin AK. Pitfalls of conducting and interpreting estimates of energy availability in free-living athletes. Int J Sport Nutr Exerc Metab. 2018;28(4):350-63.

6. Viner RT, Harris M, Berning JR. Energy availability and dietary patterns of adult male and female competitive cyclists with lower than expected bone mineral density. Int J Sport Nutr Exerc Metab. 2015;25(6):594-602.

7. Melin A, Tornberg AB, Skouby S, Faber J, Ritz C, Sjödin A, et al. The LEAF questionnaire: a screening tool for the identification of female athletes at risk for the female athlete triad. Br J Sports Med. 2014;48(7):540-5.

8. Guillemin F, Bombardier C, Beaton D. Cross-cultural adaptation of health-related quality of life measures: literature review and proposed guidelines. J Clin Epidemiol. 1993;46(12):1417-32.

9. Beaton DE, Bombardier C, Guillemin F, Ferraz MB. Guidelines for the process of cross- cultural adaptation of self-report measures. Spine (Phila Pa 1976). 2000;24(31):86-91.

10. Melissant HC, Neijenhuijs KI, Jansen F, Aaronson NK, Groenvold M, Holzner B, et al. A systematic review of the measurement properties of the Body Image Scale (BIS) in cancer patients. Support Care Cancer. 2018;26(6):1715-26.

11. Streiner DL, Norman GR. Health Measurement Scales (a pratical guide to theirs development and use). 4th ed. Oxford, England: Oxford University Press; 2008

12. Meyer NL, Sundgot-Borgen J, Lohman TG, Ackland TR, Stewart AD, Maughan RJ, et al. Body composition for health and performance: a survey of body composition assessment practice carried out by the Ad Hoc Research Working Group on Body Composition, Health and Performance under the auspices of the IOC Medical Commission. Br J Sports Med. 2013;47(16):1044-53.

13. Terwee CB, Bot SD, De Boer MR, Van Der Windt DA, Knol DL, Dekker J. Quality criteria were proposed for measurement properties of health status questionnaires. J Clin Epidemiol. 2007;60(1):34-42

14. Bland JM, Altman DG. Statistical methods for assessing agreement between two methods of clinical measurement. Lancet. 1986;1(8476):307-10.

15. McNemar Q. Note on the sampling error of the difference between correlated proportions or percentages. Psychometrika. 1947;12(2):153-7

16. IBM Corp. Released 2013. IBM SPSS Statistics for Windows. Version 22.0. Armonk, NY: IBM Corp.

17. Hambleton RK, Patsula L. Increasing the validity of adapted tests: myths to be avoided and guidelines for improving test adaptation practices. J Appl Test Technol. 2009;1(1):1-30.

18. Acquadro C, Conway K., Hareendran A, Aaronson N, European Regulatory Issues and Quality of Life Assessment (ERIQA) Group. Literature review of methods to translate health-related quality of life questionnaires for use in multinational clinical trials. Value Health. 2008;11(3):509-21.

19. Pasquali L. Princípios de elaboração de escalas psicológicas. Rev Psiquiatr Clin. 1998;25(5):206-13.

20. Slater J, Mclay-Cooke R, Brown R, Black K. Female recreational exercisers at risk for low energy availability. Int J Sport Nutr Exerc Metab. 2016;26(5):421-7.

21. Black K, Slater J, Brown RC, Cooke R. Low energy availability, plasma lipids, and hormonal profiles of recreational athletes. J Strength Cond Res. 2018;32(10):2816-24.

22. Meng K, Qiu J, Benardot D, Carr A, Yi L, Wang J, et al. The risk of low energy availability in Chinese elite and recreational female aesthetic sports athletes. J Int Soc Sports Nutr. 2020;17(1):13.

23. Terwee CB, Mokkink LB, Steultjens, MP, Dekker J. Performance-based methods for measuring the physical function of patients with osteoarthritis of the hip or knee: a systematic review of measurement properties. Rheumatology (Oxford). 2006;45(7):890-902.

24. Waltz C, Strickland OL, Lenz ER. Measurement in nursing research. 4th ed. New York: Springer; 2010.

25. Ackland TR, Lohman TG, Sundgot-Borgen J, Maughan RJ, Meyer NL, Stewart AD, et al. Current status of body composition assessment in sport: review and position statement on behalf of the ad hoc research working group on body composition health and performance, under the auspices of the I.O.C. Medical Commission. Sports Med. 2012;42(3):227-49

26. Torstveit MK, Sundgot-Borgen J. The female athlete triad: are elite athletes at increased risk? Med Sci Sports Exerc. 2005;37(2):184-93.

27. Logue DM, Madigan SM, Heinen M, Mcdonnell SJ, Delahunt E, Corish CA. Screening for risk of low energy availability in athletic and recreationally active females in Ireland. Eur J Sport Sci. 2019;19(1):112-22. 